\title{
Are octroyed Constitutions of the 19th century to be considered as imposed Constitutions?
}

Jörg Gerkrath*

The following contribution contemplates so-called 'octroyed', 'conceded' or 'granted' constitutions of $19^{\text {th }}$ century Europe whose common roots are to be found in the French Charte constitutionnelle of 1814. Strongly influenced by the spirit of Restoration and based on the monarchical principle, as reaffirmed by the Congress of Vienna (1814-1815) and the founding act of the German Confederation (1820) ${ }^{1}$, these Charters stem from a paternalistic process of domestic constitution-making without any direct involvement of (a body representing) the people.

The terminology employed in legal literature to examine the phenomenon is not entirely fixed. Although English speaking scholars refer predominantly to 'conceded' or 'granted' constitutions, it appears to be more adequate to speak of 'octroyed' constitutions. The term 'octroyed' is commonly used in its different linguistic expressions in those countries which experienced significant periods of octroyed constitutions: in German, oktroyierte Verfassung, in French, constitution octroyée, in Italian, costituzione ottriata and, in Portuguese, constituição outorgada.

The French Charter of 1814, the archetype of all octroyed constitutions, contains the following royal statement at the very end of its preamble: 'Nous avons volontairement et par le libre exercice de notre autorité royale accordé, et accordons, fait concession et octroi à nos sujets, tant pour nous que pour nos successeurs et à toujours, de la charte constitutionnelle qui suit ${ }^{2}$ Clearly the three terms are used together in that occasion. Hence, from a linguistic, as well as from a legal-historical perspective, the adjectives 'granted' and 'conceded' might be used as synonyms of 'octroyed'. But as we are dealing here with a matter of constitutional law and theory where language matters and as we are striving to develop convincing elements of a theory of octroi in constitution making, this contribution will therefore promote the corresponding vocabulary, even though the above quoted final sentence of the preamble of the

\footnotetext{
“Professor of Public and European Law at the University of Luxembourg, jorg.gerkrath@uni.lu.

${ }^{1}$ Final Act of the Ministerial Conference to Complete and Consolidate the Organization of the German Confederation, signed by the parties May 15, 1820.

${ }^{2}$ Which may be traduced as: 'We have voluntarily and by the free exercise of our royal authority granted, and grant, made concession and octroi to our subjects, both for us and for our successors and forever, the constitutional charter that follows'.
} 
French Charter of 1814 contains the only explicit mention of the term octroi in a constitutional document of the considered period. Regarding all the other constitutional documents, the designation 'octroyed' was introduced later by literature.

The paper intends to fill a gap in legal literature. Besides a stimulating contribution of Luigi Lacchè, Professor in Legal History at the University of Macerata, on the very theory of octroi, ${ }^{3}$ and a synthetic Encyclopedia entry authored by Yasuo Hasebe, ${ }^{4}$ the lack of comprehensive comparative literature on the technique of constitutional octroi is obvious. ${ }^{5}$ All other relevant works (known by the author) are based on the study of one single charter or an analysis of constitutions from a single country. ${ }^{6}$

This study does not pretend to constitute a fully-fledged comparative work. It is more of an essay aiming at defining criteria allowing us a) to better understand the concept of an octroyed constitution, and b) to find out whether an octroyed constitution is equivalent to an imposed one. Nevertheless, the inquiry faces some of the same challenges and has to comply with the methodology of Comparative Law, as far as possible. ${ }^{7}$ In the first place the tertium comparationis, that is the common quality of the charters and constitutions to be compared, needs to be properly defined.

An octroyed constitution can be described as: resulting from an authoritarian or paternalistic process of constitution-making engaged unilaterally by a monarch possessing the de facto constituent power and exercising it without the direct involvement of a body representing the people. By this act, the formerly absolute

\footnotetext{
${ }^{3}$ Published in three different language versions: Luigi Lacchè, 'Granted constitutions: The theory of octroy and Constitutional Experiments in Europe in the aftermath of the French Revolution' (2013) 9 EuConst, 285; 'Las Cartas otorgadas. La teoría de l'octroi y las experiencias constitucionales en Europa post-revolucionaria' (2010) 6 Fundamentos 269; 'Le carte ottriate, La teoria dell'octroi e le esperienze costituzionali nell'Europa post-rivoluzionaria' (2009) 18 Giornale di storia costituzionale 229.

${ }^{4}$ Yasuo Hasebe, 'Imposed Constitutions (constitutions octroyées)', Max Planck Encyclopedia of Comparative Constitutionnal law (2016) <http://oxcon.ouplaw.com/view/10.1093/law-mpeccol/lawmpeccol-e21> accessed on 10 September 2017.

${ }^{5}$ cf also Oscar Ferreira, 'Les équivoques du „constitutionnalisme octroyé: un débat transatlantique l' (2015) 16 Historia Constitucional 67. The author focused on the French Charter of 1814 and unfortunately didn't publish yet the second part of his work, intended to deal with octroyed constitutionalism in Portugal and Brazil.

${ }^{6}$ cf notably Philippe Lauvaux, 'La technique de l'octroi et la nature de la Charte' (2014) 13 Jus politicum 1.

${ }^{7}$ As exposed by Léontin-Jean Constantinesco, Rechtsvergleichung. Die vergleichende Methode, vol 2 (Carl Heymanns Verlag 1972). Regarding the methodology of comparative constitutional law cp Vicki C. Jackson, 'Comparative Constitutional Law: Methodologies' in Michel Rosenfeld, András Sajó (eds), The Oxford Handbook of Comparative Constitutional Law (OUP 2012).
} 
sovereign renounces - in theory spontaneously and irrevocably - to a part of his own exclusive authority. ${ }^{8}$ In reality, such acts of constitutional voluntarism were intended to conceal the need to compromise with social reality. ${ }^{9}$

Jon Elster distinguishes two forms of constitution-making by a single founder: „In one, a wise man writes a constitution for his community and then withdraws from politics. Plutarch tells us that Solon and Lycurgus (if he existed) took this path. It has never been followed again'. One could, however, object that the Brazilian Emperor and King of Portugal, Don Pedro IV, precisely followed this example when he octroyed the Portuguese Carta constitucional in 1926 and abdicated from the Portuguese throne a few days later. ${ }^{10}$ In the other case, Elster pursues, 'a ruler, presumably assisted by advisors, imposes an 'octroyed' constitution on his people. The French Charter of 1814 and Prussian constitution of 1850 are often cited as examples'. ${ }^{11}$

As an 'octroyed constitution' is evidently enacted top-down by a monarch, there is some confusion to be found in legal literature regarding the concept of an 'imposed constitution' and the 'technique of constitutional octroi'. In their contribution to the Oxford Handbook of Comparative Constitutional Law, devoted to 'Process' and within their developments about 'constitution-making as an international effort', Claude Klein and András Sajó consider for instance that 'the involvement (of the occupying power) may reach the level of imposition (constitutional octroy)' and refer in a footnote to 'various forms of colonization'. ${ }^{12}$

Yasuo Hasebe applies the same inaccuracy considering: 'Inherent in this concept of imposed constitution is the assumption that constituent power belongs to the people. Therefore, a constitution which the monarch concedes to his subjects (constitution octroyée) is also a kind of imposed constitution'. ${ }^{13}$ His affirmation contains a striking anachronism as, at the time when constitutions could legitimately be octroyed by a

\footnotetext{
${ }^{8}$ cf Paolo Biscaretti di Ruffia, Stefan Rozmaryn, La Constitution comme loi fondamentale dans les Etats de l'Europe occidentale et dans les Etats socialistes (LGDJ 1966) 29.

${ }^{9}$ Lauvaux (n 6) 2.

${ }^{10} \mathrm{cf}$ Jorge Miranda, Manual de direito constitucional. O sistema constitucional português vol $1\left(10^{\text {th }}\right.$ edn, Coimbra Editora 2014) 40.

${ }^{11} \mathrm{cf}$ Jon Elster, 'Constitutions and constitution-making' <http://www.ccpds.fudan.edu.cn> accessed on 10 September 2017.

${ }^{12}$ Claude Klein, András Sajó, 'Constitution-Making: Process and Substance' in Michel Rosenfeld, András Sajó (eds), The Oxford Handbook of Comparative Constitutional Law (OUP 2012) 432.

${ }^{13}$ Hasebe (n 4) para 2.
} 
monarch holding the plenitudo potestatis, the democratic principle had not yet successfully superseded the monarchical principle.

A similar misunderstanding can be found regarding Cyprus. As well known, the Constitution of Cyprus did not emanate from the free will of its people but was in fact imposed on the population by the London and Zürich Agreements of 1959, concluded between representatives of the two Cypriot communities of the one part, and Greece, Turkey and the United Kingdom of the other part. Considering, as Tornaritis does: „It is, therefore (...) of the nature of a granted Constitution - constitution octroyée, which in the monarchical times of the past centuries the monarch condescended to grant to his people, but is not consistent with the new prevailing democratic principles under which the constituent power vests in, and is exercised by, the people', isn't helping to understand the true nature of the Constitution of Cyprus. ${ }^{14}$

At first glance, it does not seem accurate to use the same terminology for such different realities as constitutional charters granted by monarchs of the early 19th century and a Constitution imposed by means of an international agreement in 1959 . But could it be as simple as to distinguish 'domestically octroyed' constitutions on the one side and 'internationally imposed' constitutions of the other side? Or, in other words, would the main question be whether external or internal patrons put a given constitution in place? In this event, however, how should we deal with constitutional charters octroyed by a monarch ruling on two countries which are linked through his person in a so-called personal or real union? This was precisely the case in Poland (1815), Portugal (1826) and Luxembourg (1841).

It goes without saying that in my opinion octroyed constitutions can never be seen as 'democratically established constitutions'. One could consider them as a subdivision of 'imposed constitutions', even though they show a number of specific characteristics which distinguish them clearly from imposed constitutions in the usual sense. The expression 'constitutional octroi' should not be used as a synonym for any process leading to an 'imposed Constitution'. This paper aims to develop and to validate or invalidate the value of a series of distinctive criteria and possible elements of a definition of 'octroyed' constitutions in order to underline their specificity.

\footnotetext{
${ }^{14} \mathrm{cf}$ Criton G. Tornaritis, Cyprus and its Constitutional and Other Legal Problems ( $2^{\text {nd }}$ ed, Nicosia 1980) 54.
} 
In order to avoid any kind of anachronism, the different charters need to be understood within their historical as well as their political context. ${ }^{15}$ Before starting to discuss the criteria that I consider to be distinctive of octroyed constitutions, it seems indicated to give some preliminary consideration to the dissemination of the phenomenon and to define the scope of this study.

\section{Dissemination of the phenomenon and scope of the study}

The constitutions of a given country certainly are 'the product of historical circumstances and the reflection of certain political, economic, social and cultural elements'. ${ }^{16}$ In order to compare the comparable, this contribution will only consider octroyed constitutions enacted in $19^{\text {th }}$ century Europe.

The golden age of octroyed constitutions is the first half of the $19^{\text {th }}$ century and more precisely the period from 1814 to 1850 . This period can be identified as an own 'cycle' of constitution making. We can call it the 'restoration cycle'. ${ }^{17}$ Each of the octroyed constitutions is indeed a historical product linked to the specific transitional period called Restoration or the restorative period. They stand as necessary first or intermediate acts of constitutionalism and transitional steps towards the emergence of parliamentarism and the final victory of the idea of the people as only legitimate constituent power. German authors generally refer to the constitutions of this period as inspired by the principle of dualism (Dualismus). In the German constitutional monarchies of the early $19^{\text {th }}$ century it was indeed possible to observe what Carl Schmitt called a 'dualistic intermediate status' (dualistischer Zwischenzustand). ${ }^{18}$

Nevertheless, not all constitutional documents adopted during this period have been octroyed unilaterally by a monarch. Amongst the main exceptions to be mentioned is the Dutch Grondwet from 1814. Adopted by an Assembly of six-hundred notables convened in Amsterdam in March 1814, its preamble nevertheless opened with the words: 'We, William, by the grace of God'. Despite not technically being a charte octroyée, the Fundamental Law was indeed 'a typical product of Restoration

\footnotetext{
${ }^{15}$ All mentioned documents have been studied in their original linguistic versions and the relevant literature in English, French, German and Portuguese has been taken into account.

${ }^{16}$ cf Miranda (n 10) 9, considering the caracteristics of portuguese constitutionalism.

17 cf José Joaquim Gomes Canotilho, Direito Constitucional e Teoria da Constituição $\left(7^{\text {th }}\right.$ edn, Coimbra Editora 2003) 134, who speaks of restoration constitutionalism (o constitucionalismo da Restauração).

${ }^{18}$ Carl Schmitt, Verfassungslehre ( $8^{\text {th }}$ edn, Duncker \& Humblot 1993) 54.
} 
constitutionalism'. ${ }^{19}$ So is the Dutch Grondwet of August 24, 1815 which results from a revision of the Grondwet 1814 and is still in place. The Norvegian Grunnloven of May 17, 1814 likewise was elaborated within a Constitutional Imperial Assembly. ${ }^{20}$ Furthermore, several member states of the German Confederation adopted constitutions in the 1830's in the form of constitutional pacts. The Kingdom of Württemberg reached this stage pre-eminently in 1819.

Finally, a specific case to be mentioned is the Estatuto de Bayona of July 6, 1808, the first written Spanish constitution, even though it had no practical significance because it never entered into force. The Estatuto was an octroyed constitution by which Napoleon wanted to impose an autocratic system on Spain. In the preamble the constitution is presented as a pact between the king and his people. In reality, it was more like a constitutional octroi by Napoleon who previously had presented a draft to an assembly of Spanish notables, and only 75 (91 at the final session) out of 175 appeared when asked to do so. ${ }^{21}$

During the considered period of Restoration more or less influential constitutional documents have been octroyed in about a dozen European countries. Some of them broke records in terms of longevity, others had a rather ephemeral lifespan. When on the $4^{\text {th }}$ of June 1814 Louis XVIII granted the French 'Charte constitutionnelle', often referred to by scholars as the prototype of an octroyed Constitution, he incidentally launched at the same time the restoration cycle. The Charte became for numerous years one of the most influential constitutional documents in continental Europe.

It inspired notably the 'Charte constitutionnelle du Royaume de Pologne', the constitution granted by Tsar Alexander I in his role as King of Poland on November 27, 1815, executing an obligation laid down in article I of the Final Act of the Congress of Vienna. The Charter was proclaimed by the Tsar both in its original French and a translated Polish version. ${ }^{22}$ Transfer and reception of the French Charte model could also be observed in the southern German states during the

\footnotetext{
${ }^{19}$ Boris Mirkine-Guetzévitch, 'L'histoire constitutionnelle comparée' (1936) Annales de l'Institut de Droit comparé de l'Université de Paris II 86, 93.

${ }^{20}$ cf Ulrike Müßig, 'Juridification by Constitution. National Sovereignty in Eighteenth and Nineteenth Century Europe' in Ulrike Müßig (ed) Reconsidering Constitutional Formation I, National Sovereignty, A comparative Analysis of the Juridification by Constitution (Springer Open 2016) 56.

${ }^{21}$ cf Müßig (n 20) 36 : 'This constitutional octroi of July 6, 1808 based on monarchical prerogatives of the intruder king (rey intruso) was widely rejected by the people as a sign of French foreign rule.'

${ }^{22}$ cf Markus J. Prutsch, Making Sense of Constitutional Monarchism in Post-Napoleonic France and Germany (Palgrave Macmillan 2013) 61.
} 
period termed early constitutionalism (Frühkonstitutionalismus). ${ }^{23}$ The constitutions (Verfassungsurkunden) of Nassau (September 2, 1814), Württemberg (Landständische Verfassung of March 15, 1815), Sachsen-Weimar-Eisenach (May 5, 1816), Bayern (May 26, 1818) and Baden (August 22, 1818) have indeed all been octroyed by reigning monarchs who wanted to secure their authority by granting rights and freedoms to their subjects and sharing the legislative power with an elected Parliament.

Portugal experienced actually the longest period of octroyed constitutionalism (constitucionalismo outorgado) during the $19^{\text {th }}$ century. ${ }^{24}$ The Carta Constitucional $d a$ Monarquia granted by Emperor Don Pedro IV from Brazil on April 29, 1826, remained in place, beside two interludes, for seventy-two years between 1826 and $1910 .^{25}$ Influenced by the French Charter and the thinking of Benjamin Constant, it also contained many aspects copied from the Brazilian Constitution of 1824. In Spain, on the contrary, the Estatuto real of 1834 only had an ephemeral existence. The Royal Statute was put into effect on April 10, 1834 by the Regent Maria Christina in the name of her daughter Isabella II in absence of any democratic consent. After a short and troubled period, Regina Maria Christina, re-established the constitution of Cádiz on August 13, 1836.

Luxembourg's constitutional history displays two cases of octroi. The first occurred in 1841, when William II, King of the Netherlands and Grand-Duke of Luxembourg, in order to comply with the provisions of the German Confederation, of which the Grand Duchy was a member, granted the Constitution d'Etats pour le Grand-Duché de Luxembourg. ${ }^{26}$ The second happened in 1856 when William III, who succeeded his father in 1849 and proved to be a militant defender of the royal prerogatives, staged a coup d'état and octroyed a constitutional revision. ${ }^{27} \mathrm{He}$ dissolved the Chamber on his own authority and promulgated a revised text of the liberal Constitution of 1848 .

\footnotetext{
${ }^{23}$ cf Jacky Hummel, 'La Charte française de 1814 et le deutscher Konstitutionalismus : les inflexions d'une réception durable' (2014) 13 Jus Politicum 1.

${ }^{24}$ Expression borrowed from José Miguel Sardica, 'A Carta Constitucional portuguesa de 1826' (2012) 13 Historia Constitucional 527, 530.

${ }^{25}$ cf Gomes Canotilho (n 17) 147.

${ }^{26}$ The royal grand-ducal ordinance of October 12, 1841, establishing the Constitution of Estates (landständische Verfassung), was published in German and French in the Legislative and Administrative Memorial no 511841425.

${ }^{27}$ cf Raymond Fuselier, Les Monarches parlementaires (Les éditions ouvrières 1960) 558 who mentions the 'revision octroyée'.
} 
The new Constitution restored monarchy and abolished the parliamentary system. Though clearly adopted in breach of the formal requirements of revision of the 1848 constitution, it was published by a royal ordinance of November 27, 1856, 'carrying revision of the Constitution'. ${ }^{28}$

Similar to the southern German states, the Italian monarchies of the $19^{\text {th }}$ century also came across the technique of constitutional octroi. The most significant document was the so-called Statuto Albertino, officially named Statuto del regno di Sardegna, granted to the kingdom of Sardinia by King Carlo Alberto on March 4, 1848. The Statuto is not an oeuvre of a parliamentary assembly. Its octroi rather points to strong parallels with the French Charter in 1814 and the constitutions of Bavaria and Baden in 1818. Their common aim was to protect royal authority by an 'eternal and irrevocable fundamental law of the monarchy'. ${ }^{29}$

The Albertine Statute was also consistent with other Italian constitutions of 1848 , which drew inspiration from the French Charter. Such were the Constitution of the Kingdom of the Two Sicilies (February 10, 1848) and the Statute of the Grand Duchy of Tuscany February 15, 1848). Being written in order to subdue popular uprisings, they were brief and laconic and left a lot to constitutional practice. But these charters had a very brief lifespan and were unable to translate their goals into practice. ${ }^{30}$ In contrast to the Statuto Albertino which later became the constitution of the unified Kingdom of Italy and remained in force, with changes, until 1948.

At the end of the Restoration cycle of constitution-making by octroi, we finally encounter the experiences of Prussia and Austria. The Constitution of Prussia (Verfassungsurkunde für den preußischen Staat) was octroyed by Friedrich Wilhelm, King of Prussia by the grace of God, on December 5, 1848, after having dissolved a constitutional convention previously convened. It was definitively confirmed by the King on January 31,1850 , once revised and accepted by both chambers according to the reservation stated in the preamble of 1848 and according to the amendment procedure laid down in article 112. Thus, this specimen of an oktroyierte Verfassung

\footnotetext{
${ }^{28}$ cf Paul Eyschen, Das Staatsrecht des Grossherzogtums (Paul Siebeck 1890) 10, Pierre Majerus, L'Etat luxembourgeois (Saint.Paul 1990) 26, and Luc Hommel, Les étapes constitutionnelles du Grand-Duché de Luxembourg (L'édition universelle 1935) 11.

${ }^{29}$ As states the final line oft the Statuto's preambel: '(...) abbiamo ordinato ed ordiniamo in forza di Statuto e Legge fondamentale, perpetua ed irrevocabile della Monarchia, quanto segue: (...)'.

${ }^{30}$ Müßig (n 20) 175.
} 
was in fact octroyed, revised, accepted by Parliament and finally proclaimed by the King in an unprecedented four step procedure.

Concerning Austria, the Empire constitution of March 4, 1849, the so-called 'oktroyierte Märzverfassung', is similarly a result of a sequence of four imperial patents proclaimed by Ferdinand I. It is also known as 'Count Stadion constitution', Count Franz Stadion being the Interior Minister who drafted it, while the constitutional committee of the Parliament was preparing a rival draft constitution. ${ }^{31}$

The phenomenon of constitutional octroi did not fully disappear with the end of the Restoration period. There are still some examples of $20^{\text {th }}$ century octroyed constitutions to be discovered in the Eastern part of the European continent as for instance: The Serbian Constitution of 1901, granted by Alexander I of Serbia; the Russian Fundamental Laws of 1906, conceded by Tsar Nicholas II; the constitution of Lithuania of May 15, 192832; and the Constitution of Yugoslavia of September 3, 1931, proclaimed by Alexander I. But even in the heart of western Europe the Principality of Monaco received a first 'Acte constitutionnel' by octroy in 1911 . The more recent Monegasque Constitution of December 17, 1962 - even though prepared consensually - is still considered being a charte octroyée, according to an opinion of the Venice Commission. ${ }^{33}$

As we have seen, octroyed constitutions were adopted primarily in continental Europe. However, the phenomenon has never been limited to the 'triangle consisting primarily, but not exclusively, of France from 1814 until 1830; secondly of the German lands from the Congress of Vienna ; and thirdly, of the Italian states, in particular the Kingdom of Sardinia', as suggested by Luigi Lacchè. ${ }^{34}$ Geographically speaking, it could also be observed outside of Europe. A first example is the Ottoman Basic Law (Kānūn-ı Esāsī), promulgated by Sultan Abdülhamit II on December 23, 1876. The Constitution was prepared by a commission directly assigned by the

\footnotetext{
${ }^{31} \mathrm{cf}$ on this interesting period Eric Voegelin, Ruth Hein (tr), Gilbert Weiss (ed), The Authoritarian State: An Essay on the Problem of the Austrian State. Collected Works of Eric Voegelin vol 4 (University of Missouri Press 1999) 130.

${ }^{32}$ This dictatorial constitution had been octroyed by the President of the Republic, Anton Smetona. It was repealed in 1938 and remained widely unapplied. cf Wolfgang Ismayr, Die politischen Systeme Osteuropas (2nd ed, Leske+Budrich 2013) 156.

${ }^{33}$ Commission européenne pour la démocratie par le droit, CDL-AD(2013)018, avis no. 695/2012 sur l'équilibre des pouvoirs dans la constitution et la legislation de la Principauté de Monaco, Strasbourg 18 June $2013,9$.

${ }^{34}$ Lacchè (n 3) 286.
} 
Sultan and published in Turkish with an official translation in French. ${ }^{35}$ As an unilateral declaration of the Sultan, it is to be considered as an octroyed constitution. ${ }^{36}$ A second example is the well-known Japanese Meiji constitution of February 11, 1889; and a third one is the 'Fundamental State Laws of the Russian Empire' of April 23, 1906, granted by Tsar Nicholas II and preceded by the 'October Manifesto' of October 17, 1905 forming „a typical act of octroyed constitutionalism'. ${ }^{37}$

I have only taken into account the octroyed constitutions adopted in European monarchies between1814 and 1850. In order to illustrate their distinctive patterns, I will mainly refer to the following six historical exemplars: France 1814, Portugal 1826, Luxembourg 1841, Italy 1848, Austria 1849 and Prussia 1848/1850. Although there are of course many differences to be observed, these constitutions have sufficient elements in common to illustrate what makes the category of octroyed constitutions (the tertium comparationis) unique. I will elaborate on five elements or criteria, which are all classical criteria in constitutional thought, and which I consider decisive for the understanding of octroyed constitutions: Process (II.), Form (III.), Legitimacy (IV.), Substance (V.) and Amendment (VI.).

\section{Process: the technique of octroi, a constitutional bluff?}

An octroi is a monarchical proceeding to establish a constitution (oktroyierte Verfassung). It is classically opposed to a second proceeding, which is the pact concluded between the monarch and the people, represented by Parliament (paktierte Verfassung). Octroyed constitutions are, in theory, voluntary concessions of absolute rulers. In practice, however, it was simply and only under the pressure of events that monarchs abandoned a fraction of their sovereignty. ${ }^{38}$ Accordingly, there are some prejudices to get rid of. As we will see, the constitutional octroi never resulted from the monarch's free will alone, mostly it wasn't even a true unilateral act,

\footnotetext{
${ }^{35}$ Abdolonyme Ubicini, La Constitution ottomane du 7 zilhidjé 1293 (23 décembre 1876). Expliquée et annotée (Cotillon 1877).

${ }^{36}$ Ergun Özbudun, 'The Ottoman Constitution of 1876' Max Planck Encyclopedia of Comparative Constitutional Law, (2016) <http://oxcon.ouplaw.com/view/10.1093/law-mpeccol/law-mpeccol-e639> accessed on 10 September 2017; Aslı Topukcu, 'The processes and the principles of constitutional design in Turkey. Historical and legal perspective', Paper presented to the World Congress of Constitutional Law, Oslo 2014, <https://www.jus.uio.no/english/research/news-andevents/events/conferences/2014/wccl-cmdc/wccl/papers/ws11/w11-topukcu.pdf > accessed on 10 September 2017.

${ }^{37}$ cf Andrei Medushevsky, Russian Constitutionalism: Historical and Contemporary Development (Routledge 2006) 124.

${ }^{38}$ cf Joseph Barthélemy, Précis de droit constitutionnel (4th edn, Dalloz 1938) 110.
} 
nor a product of the monarch's sole authorship and it has often to be considered within a sequence of several royal acts. Altogether this points to the direction that the performance of octroying a constitutional charter has to be seen as what it really is: a royal ruse and a constitutional bluff.

Rather than an acting of their free will, monarchs deciding to proceed to a constitutional octroi did regularly belief to fulfil a moral obligation towards their subjects or even to execute a legal obligation laid down in a superior document. The historical circumstances created by the Parisian peace treaties of 1814 and 1815, the course of the Vienna Congress and the establishment of the German Confederation strongly promoted this development.

In France, Louis XVIII was pushed by his counsellors to 'concede rather than receive' a constitution. And at the same time, the allied powers had made clear during the conclusion of the first peace treaty of Paris on May 30,1814, that they wouldn't leave the French territory unless a government was established on constitutional foundations. ${ }^{39}$ The preamble of the second peace treaty of Paris, concluded after Napoleon's return and the so-called '100 days' on November 22, 1815, refers consequently to the octroyed charter of $1814 .^{40}$

The Congress of Vienna had also a noteworthy influence. According to article I of the Final Act of June 8, 1815, Tsar Alexander I of Russia was obliged to give a constitution to the newly recreated Poland, the so-called 'Congress-Poland'. In addition, article XIII of the founding Act of the German Confederation (Deutsche Bundesakte), adopted during the Congress of Vienna, founded a duty to establish a 'constitution of Estates' in all of the member states, but without prejudicing the procedure to follow. ${ }^{41}$ Article XIII of the Federal Act was largely responsible for the German early constitutionalism, especially in the southern German states. Some of the member states' constitutions referred explicitly to this duty. The preamble of Luxembourg's constitution of Estates of 1841 did so, and the octroyed revision of 1856 was also explicitly motivated by the obligation of the king-grand duke to comply

\footnotetext{
${ }^{39}$ cf Hummel (n 23) 6.

40 'Participating at present with his Most Christian Majesty in the desire to consolidate, by maintaining inviolate the Royal Authority, and by restoring the operation of the Constitutional Charter, the order of things which had been happily re-established in France, as also in the object of restoring between France and her Neighbours those relations of reciprocal confidence and goodwill which the fatal effects of the Revolution and of the system of conquest had for so long a time disturbed (...)'.

${ }^{41}$ Article XIII : 'In allen Bundesstaaten wird eine landständische Verfassung stattfinden.'
} 
with the federal duty to respect the principles of the German Confederation. The octroyed constitution of Württemberg of 1815 also contains the expression. ${ }^{42}$ Beyond this legal duty, most certainly other underlying motivations of an octroi prevailed: the unification of territorial gains, the consolidation of finances and the demonstration of the new state's sovereignty. ${ }^{43}$

Regarding the unilateral nature of an octroi, things aren't by far as clear as they seem. German scholars started in the $19^{\text {th }}$ century to oppose constitutional octrois and constitutional pacts as two different models, the former uni-, the latter bilateral. But still, an octroi can be understood as the fulfillment of a promise by a monarch, who sacrifices some of his powers in establishing a constitutionally limited monarchy and in doing so makes a gift to his subjects who accept it. In this sense the octroi results from a kind of dialogue, which is different than a joint and bilateral constitution-making procedure involving a ruler and an assembly. But it isn't truly unilateral either.

The octroi appears as a kind of transactional measure, even though the degree of popular consent varies naturally. The strongest case was to be found in Prussia in $1848 / 1850$ where the octroyed constitution required a revision to be voted by the two chambers in order to become effective. But also in Austria the imperial patent (constitutional act) that introduced the Pillersdorff Constitution on April 25, 1848 'appears as the fulfilment of a fundamental obligation toward the contractual partner, the people'. ${ }^{44}$ In one case, as in Bohemia in October 1871, a nation of the Austrian Empire considered an octroi by the shared dynast to be a satisfaction of their own demands rather than a unilateral absolute action. Such a 'requested octroi' was 'understood as something to be granted or bestowed, not as something to be imposed'. ${ }^{45}$ In this understanding the people relied on a virtual (moral) compact between the monarch and itself.

Taking a closer look at the drafting procedure of the constitution, which usually precedes its formal octroi, a distinction between the author (auteur) and the writer

\footnotetext{
${ }^{42} \mathrm{cf}$ Ernst Rudolf Huber, Deutsche Verfassungsgeschichte seit 1789. Band I: Reform und Restauration 1789 bis 1830 (2nd edn, W. Kohlhammer 1967) 640.

${ }^{43}$ cf Hummel (n 23) 5-6; Ulrike Müßig, Die europäische Verfassungsdiskussion des 18. Jahrhundert (Mohr Siebeck 2008) 91.

${ }^{44}$ Voegelin (n 31) 131.

${ }^{45}$ ibid
} 
(écrivain) of the constitution is suggested in literature. Some go as far as to consider the king being only the writer, writing down what the true author, the nation, accepted. ${ }^{46}$ In any case, the monarch assisted by advisors, counsellors and drafting committees, is always more or less actively involved in the editing of the text. In some cases, like in Bavaria, he would nominate a constitutional committee charged to prepare a draft. ${ }^{47}$ In others, like in Prussia, a reluctant Monarch who wanted to keep his promise of a constitution to be agreed upon with an elected Parliament, had to be convinced by his ministry to proceed by octroi. ${ }^{48}$ The drafting of the Portuguese Charter in 1826 constitutes another interesting example. Don Pedro IV, emperor of Brazil, assisted by his counselor, Francisco Gomes da Silva, prepared this text in a few days by working on a draft of the Brasilian Constitution from 1823. Each of the two worked on a paper copy, which was revised and annotated and then switched between them. ${ }^{49}$

Frequently the octroi wasn't an isolated act but resulted from a sequence of acts adopted in a step-by-step process as the constitution was announced by preceding declarations or statements, for instance. The Declaration of Saint-Ouen, made by the future Louis XVIII on May 2, 1814, may illustrate this. Upon landing in France, the future king rejected the provisional constitution proposed by the Senate but promised to adopt a new 'liberal constitution'. This promised constitution was eventually adopted in the Charter of 1814 . He later sought to eradicate the legal effects of the initial compromise in a third step by establishing the offence of criticising the octroi by a statute of March 22, $1822 .{ }^{50}$ The Austrian Empire faced a similar sequence of several constitutional patents between April 1848 and March 1849. A first patent of March 15, 1848 promised a constitutional charter, which was octroyed on April 25, 1848, the so-called Pillersdorffsche Verfassung. It was declared provisional in May 16, 1848, withdrawn in July by the Emperor and replaced by the 'oktroyierte Märzverfassung' of March 4, 1849, which itself was repealed by the New Year's Eve Patent (Silvesterpatent) of Emperor Franz Joseph I on December 31, 1851.

\footnotetext{
${ }^{46}$ cf Ferreira (n 5) 115.

${ }^{47}$ On the constitutional committee nominated in the Kingdom of Bavaria by a royal edict of September 17, 1814, see Hummel (n 23) 6; Eberhard Weis, ,Zur Entstehungsgeschichte der bayerischen Verfassung von 1818. Die Debatten in der Verfassungskommission von 1814/15' (1976) 39 ZBLG 414.

${ }^{48}$ cf Michael Kotulla, Das konstitutionelle Verfassungswerk Preußens 1848-1918 (Springer 2012) 13.

${ }^{49}$ On the drafting process cf Miranda (n 10) 39.

${ }^{50}$ cf Ferreira (n 5) 114
} 


\section{Form: how to avoid any reference to revolutionary constitutionalism}

As in architecture, on could assume as well in constitutional theory that 'form follows function'. Octroyed constitutions were intended to restore the belief in the monarchical principle, but at the same time had to conceal with social reality and could not possibly ignore all revolutionary achievements and liberal demands. Their function was to restore the authority of a monarch by absorbing parts of the revolutionary acquis. ${ }^{51}$ Or, as Eric Voegelin phrased it: 'The authoritarian gesture of the monarch, appointed by the grace of God to see to the welfare of his subjects, captures the revolutionary element of the movement for a constitution and transforms it into an act by the monarch'. ${ }^{52}$

This function could only be assumed by presenting the octroi as a gift of the enlightened monarch and thereby avoiding any reference to the constitutional theory, vocabulary and proceedings invented during the preceding revolutionary periods in Europe. Formal elements of octroyed constitutions, such as their title, wording, style, preambles, and the legal form chosen for enactment, reveal this specific function. The compromise consists of making concessions with regard to the substance but remaining firm on the form of the octroi.

This becomes most visible with the denomination chosen for the constitutional document. In France the expression 'charte constitutionnelle' was deliberately picked after having discussed other solutions such as 'constitutional act', 'ordinance' and 'edict'. ${ }^{33}$ The choice denotes a strong reverence to the Magna Carta of 1215. Already the naming of the Charter as 'constitutional' was a compromise. The decision to name some of the octroyed constitutions in Italy and Spain Statuto (Estatuto) rather than Charter proceeded from similar considerations.

Following the terminology chosen by the German Federal Act of $1815,{ }^{54}$ referring in its article 13 to the duty of each member state to establish a constitution of estates (Landständische Verfassung), several member states employed this expression in the title of their constitutions. Notably Würtemberg and Luxemburg did so respectively in 1815 and 1841 . However, the term Landständische Verfassung has

\footnotetext{
${ }^{51}$ cf Lacchè (n 3) 291.

52 cf Eric Voegelin (n 31) 132.

${ }^{53}$ cf Lauvaux (n 6) 3 quoting the memories of count Beugnot.

${ }^{54}$ The 65 articles were unanimously approved by the Frankfurt Confederal Assembly on June 8, 1820.
} 
never been properly defined. In theory, it would have meant a system of corporative representation of the estates, impossible to restore within constitutional monarchies of that time. It wasn't even very clear, whether the term refers to a type of constitution or rather to a form of representation. In some English versions the term has thus been translated as 'a constitutionally guaranteed assembly of the estates of the land'. And although some octroyed documents were simply named 'constitution', as in Bavaria in 1818, the choice of the name should not be overrated.

The wording used in the corpus as well as and especially in the preambles of the octroyed charters is probably more significant. Most of the charters are undeniably preceded by preambles, or followed by a 'postamble' as in the case of the Polish Charter. The preambles are sometimes rather lengthy with up to 724 words (France 1814) or even 988 words (Austria 1849). Written in a paternalistic style the preambles insist on the monarchic principle and the generosity of the conceding monarch. They also contain hints to the expectations of the people and to preceding promises of the monarch.

In analyzing the formal instrument used to proclaim the constitutional octroi, it is possible to detect in most of the cases the classical distinction between the instrumentum and the negotium. In all examined cases the octroy takes the form of a royal act. ${ }^{55}$ Luxembourg's constitution of estates of 1841 was published in the form of a royal ordinance establishing the constitution. ${ }^{56}$ The constitution is, however, at the same time called a statute ('loi') for the purpose of its amendment (art. 52).

The form taken by the different charters and their denominations does not deprive them of the recognition as genuine constitutions. The voices of those who completely denied all constitutional nature to octroyed documents remained in the minority during the period of their greatest spread. ${ }^{57}$ The definition of the notion of constitution according to the usual functional, formal and material criteria clearly embraces the octroyed specimen.

Of course, we are confronted here with monarchical constitutionalism, and not yet representative constitutionalism. The notions and concepts to describe this

\footnotetext{
55 cf Schmitt (n 18) 52: 'ein vom König erlassenes Gesetz'.

${ }^{56}$ cf the official journal, Mémorial $n^{\circ} 51,1841$, p. 425, orig: ordonnance, Verordnung.

${ }^{57}$ cf Lacchè (n 3) 286 quoting Karl Theodor Welcker, who considered: 'eine bloss oktroyierte Verfassung ist gar keine Verfassung'.
} 
movement had to be developed successively. In Portuguese literature the term 'Chartism' (cartismo) was coined to describe the peculiarities of octroyed constitutionalism. It can be understood as an effort to develop its own constitutional concepts. In a number of respects, Chartism definitely rethought and reworked its own liberal vocabulary, redefining basic concepts such as legitimacy, representation, nature of government, or extension of suffrage (indirect and census and non-direct and extended). ${ }^{58}$

Call it octroyed constitutionalism, ${ }^{59}$ restoration constitutionalism, chartism, or monarchic constitutionalism, all of these suggestions can be considered an effort to ally both constitutionalism ancient and modern. But it has to be born in mind that there are strong differences in the meaning of 'constitutionalism' in general, with a narrow meaning in German compared to a much wider meaning in France, for instance. $^{60}$

\section{Legitimacy: reconciling conflicting sources}

The concept of Legitimacy can be understood in the divine, meta-legal or sociological 'Weberian' sense. According to German sociologist Max Weber, a political regime being legitimate means, in a descriptive sense, that its participants have certain beliefs or faith (Legitimitätsglaube) in regard to it: 'The basis of every system of authority, and correspondingly of every kind of willingness to obey, is a belief, a belief by virtue of which persons exercising authority are lent prestige'. ${ }^{61}$ The three types of political legitimacy labelled by Weber are: traditional, charismatic, and rational-legal. Constitutional legitimacy, in a normative sense, implies a justification of the constitution that must be found beyond the constitution itself. According to Matthias Hartwig, the sources of constitutional legitimacy can be found in forms of justification

\footnotetext{
${ }^{58}$ cf notably Sardica (n 24) 529.

${ }^{59}$ Though 'octroyed constitutionalism' can be taken for an oxymoron, cf Ferreira (n 5) 70.

${ }^{60} \mathrm{cf}$ on the notion of 'monarchischer Konstitutionalismus' notably Martin Kirsch, Monarch und Parlament im 19. Jahrhundert. Der monarchische Konstitutionalismus als europäischer Verfassungstyp - Frankreich im Vergleich (Vandenhoeck \& Ruprecht 1999) 40; Hummel (n 23) 1, who both point out these differences.

${ }^{61}$ Max Weber, The Theory of Social and Economic Organization (orig. Wirtschaft und Gesellschaft, Tübingen 1922, Free Press 1997) 382.
} 
as: religion, consent, minimal substantive requirements and standards developed on international level. ${ }^{62}$

Surprisingly, octroyed constitutions do not draw their legitimacy from religion alone. Once enacted, they rather combine two opposing sources of legitimacy: religion and consent. The latter is on the rise, the first declining. We will see in the next part of the contribution, to what extent they obtain additional legitimacy by fulfilling substantive requirements and early international standards. I do not share the conclusion of Yasuo Hasebe that 'how a constitution was made, or in whose name, is not so relevant to its legitimacy'. ${ }^{63}$ This aspect remains important, even though it has to be considered in conjunction with the other foundations of its legitimacy. An octroyed constitution unavoidably conceals a strong ambiguity resulting from the contradiction of two antithetic legitimacy doctrines: the monarchic principle, personified by the donor, and the representative principle, embodied by Parliament.

The divine legitimacy of the donor's power to concede the constitution was generally referred to in the preambles of the different Charters, describing the source of legitimacy as 'the grace of God' or 'the divine Providence'. In the sense of this line of reasoning, an octroyed constitution was 'legitimately imposed'. According to the monarchical principle, the king, holding the pouvoir constituant, was entitled to give a constitution by a unilateral act. ${ }^{64}$ However, as if the donation of the constitution needed additional justifications, some preambles went further and stated reasons like the request for peace, promises that had been made and even the 'expectations of enlightened Europe'. 65

Because of their nature of Charte octroyée, granted constitutions were naturally weak in regard to their (democratic) legitimisation. But at a subsequent stage, they were able to achieve some popular adherence or at least implicit consent through the election of representative bodies and the active participation of elected assemblies in the implementation of the constitution. In the case of Prussia (1848/1850), one could even observe an act of explicit consent. According to the transitional rule of article

\footnotetext{
${ }^{62}$ Matthias Hartwig, 'What Legitimises a National Constitution? On the Importance of International Embedding' in Armin von Bogdandy, Pál Sonnevend (eds), Constitutional Crisis in the European Constitutional Area (Nomos 2015) 322.

63 Hasebe (n 4) para 41.

${ }^{64}$ cf Schmitt (n 18) 52. On the monarchical principle see Friedrich Julius Stahl, Das monarchische Prinzip, eine staatsrechtlich-politische Abhandlung (Weltgeist 1845).

${ }^{65}$ Preamble of the French Charte constitutionnelle : 'l'attente de l'Europe éclairée'.
} 
112 , a compulsory revision of the document octroyed in 1848 had to take place to let the constitution become definitive. ${ }^{66}$ In the case of the Statuto Albertino, contemporaneous observers immediately attempted to re-interpret the Statuto into a convention between king and parliament. ${ }^{67}$ In such a vision an octroyed constitution could come with consent. ${ }^{68}$

Another indication for the existence of at least implicit consent is the durability of some of the octroyed charters. For memory: The Statuto Albertino remained formally in force after the Italian unification until 1946, and the Portuguese Carta of 1826 still holds the record of longevity amongst the six Portuguese constitutions adopted since 1822. We can definitely identify a kind of de facto legitimacy, in the descriptive sense, through effectivity and longevity of a constitution.

\section{Substance: 'absorbing the Revolution into the monarchy'69}

In terms of constitutional substance, octroyed charters have to be evaluated by their degree of consistency with the ideals of constitutionalism (limited government, representation, separation of powers, protection of human rights, etc.). Consequently, this degree is rather low as the spirit of restoration prevails. The ruse consisted of capturing some elements of the revolutionary and liberal achievements within a monarchical system.

The octroyed charters therefore re-affirmed the monarchical principle but established at the same time what German literature rapidly called the principle of dualism (Dualismus).$^{70}$ Predictably, the monarch retains the executive power and cedes parts of the legislative power to an assembly, justice remaining exercised in the name of the king. The transfer of competences to a parliament, consisting typically of two chambers, entails a self-limitation of the former absolute monarch and contributed to establish first practices of parliamentarism.

\footnotetext{
${ }^{66}$ cf art. 112: The present Constitution is to be made subject to a revision by (ordinary) legislation (Articles 60 and 106) immediately after the first meeting of the chambers.

${ }^{67}$ cf Giuseppe Mecca, 'The Omnipotence of Parliament in the Legitimisation Process of 'Representative Government' under the Albertine Statute (1848-1861)' in Müßig (n 20) 183.

68 cf Richard Albert, 'Imposed Constitutions with Consent?' in this volume.

${ }^{69}$ Formula borrowed from Lacchè (n 3) 291.

${ }^{70}$ Regarding the influence of dualism in Luxembourg, see Luc Heuschling, Le citoyen monarque. Réflexions sur le Grand-Duc, la famille grand-ducale et le droit de vote (Larcier 2013) 117.
} 
The Portuguese Carta innovated insofar as it introduced a fourth power, named 'Moderating Power' (Poder moderador). It attributed inter alia an absolute veto to the monarch over legislation emanating from parliament. This moderating power was the exclusive competence of the King, as supreme head of the Nation, to watch over its independence, as well as for balance and harmony among the other political powers. As the holder of this power, the King was called furthermore to convene the Cortes; to appoint the Kingdom Peers; to dissolve the Chamber of Deputies; to appoint and dismiss the Government; to suspend magistrates and to grant amnesties and pardons.

In addition, some rights are granted to the citizens. The French Charter of 1814 thus contains a chapter dedicated to the 'Public Law of the French' reaffirming liberal fundamental rights as permanent achievements of the Revolution. As the octroyed charters always strictly limited the right to vote by strict rules on censitary vote and indirect suffrage, they belong to the liberal non democratic type of Constitutions. ${ }^{71}$ In the German monarchies of the $19^{\text {th }}$ century electorate was for instance limited to less than $1 \%$ of the population for the election of the lower house.

Compared to the previous situation, however, they still do appear in a number of cases as improvements. The constitution of Prussia 1848/1850 guaranteed for instance the 'Rights of the Prussians' as citizens' rights comprising equality, personal freedom, inviolability of residence, freedom of opinion and of the press and freedom of assembly.

Some observers underline the 'incompleteness' of octroyed constitutions as one of their specific features. ${ }^{72}$ The French Charter of 1814 obviously lacks a rule of devolution of the crown and a procedure of amendment. This must be understood as an inevitable consequence of the fact that the king's sovereignty remains exterior to the granted constitution. Regarding the absence of rules of devolution of the crown, the same is true for the Constitution of Luxembourg from 1841 and even for the current constitution dating back to 1868.

\footnotetext{
${ }^{71}$ cf Dieter Grimm, 'Types of constitutions', in Michel Rosenfeld, András Sajó (eds), The Oxford Handbook of Comparative Constitutional Law (OUP 2012) 119.

${ }^{72} \mathrm{cf}$ with regard to the French Charter : Stefan Rials, 'Essai sur le concept de monarchie limitée (autour de la Charte de 1814)' in Stefan Rials (ed), Revolution et Contre-Révolution au XIXè siècle (Albatros 1987) 96.
} 
As a natural effect of the mentioned incompleteness, octroyed constitutions left a broad margin for interpretation. Their exact meaning was often disputed because of ambiguous formulations, leaving place for both a royalist and a liberal lecture. Flexibility was thus a common feature of the granted charters. As judicial review was regarded incompatible with the monarchical principle, there was no 'authentic interpreter' but the king himself.

\section{Revision: who is entitled to amend the octroi?}

The question of amendment of octroyed constitutions leads to interesting but divergent outcomes regarding existence, nature and practice of an amendment power. As a consequence of the inherent ambiguity of octroyed constitutions, many discussions took place regarding the question of the constitution's binding character on the conceding monarch. Within the German constitutional monarchies, the prevailing position was that the constitution, once granted by the king, could no longer be modified or withdrawn unilaterally. A revision had to be decided jointly by the Monarch and the people's representatives, as with ordinary laws. When, for example, the King of Hanover unilaterally abolished the constitution in 1837, this was regarded as a breach of the law, and was proclaimed as such on September 18, 1837 by seven professors of the University of Göttingen. ${ }^{73}$ For the first time in German history, they postulated the continued validity of the constitution (one of the constitutions of estates under the Federal Act) by risking their own existence. ${ }^{74}$

Their position was consistent with articles 54 and 56 of the Vienna Final Act. Article 54 reaffirmed the duty of the States to establish a constitution. The Confederal Assembly had to monitor that this regulation did not remain unfulfilled in any Confederal state. In theory, subjects were able to file a complaint if this did not happen. In practice, this meant little as long as the leading states of Austria and Prussia refrained to adopt constitutions. According to Article 56, 'the constitutions of estates standing in recognized validity can only be changed by constitutional means.' Therefore, monarchs could not lawfully change or abolish the constitution, not even in a coup d'état. The terms 'recognized validity' referred to the fact that a constitution was actually applied. The expression was meant to exclude attempts to restore

\footnotetext{
${ }^{73}$ cf Wilhelm Bleek, Bernhard Lauer, 'Protestation des Gewissens. Die Rechtfertigungsschriften der Göttinger Sieben' (2012) 36 Schriften der Brüder Grimm-Gesellschaft.

${ }^{74}$ In fact all of them were dismissed and three even banished from the country.
} 
ancient constitutional law, theoretically valid, which had not been applied since absolutism.

The donor's de facto power to revoke the Constitution unilaterally did not disappear completely. The Austrian Empire created the precedent. First the Pillersdorffsche Verfassung was repealed in July 1848 and later replaced by the octroyed Constitution of March 1849. But the latter was once more retracted by the imperial patent of 31 December 1851 , the so-called Silvesterpatent. ${ }^{75}$ So, a process of neoabsolutist reorganization of the state, announced since the defeat of the Vienna uprising in October 1848, took place in the Austrian Empire.

During the Restoration period it wasn't evident at all how to establish a 'pouvoir constituant dérivé' distinct from the monarch's 'pouvoir constituant originaire'. In some cases, the question was therefore simply left open. The French Charter of 1814 gave the example. In absence of an explicit amendment procedure, it was in fact amended either following the ordinary legislative procedure or, in case of necessity acknowledged by the king, by royal ordinances. ${ }^{76}$ The only tangible obstacle to amendments was the promise made by Louis XVIII at the end of the preamble octroying the Charter 'both for him and his successors and forever'. ${ }^{77}$ But this promise could easily be modified by agreement between the King, holding the monopoly of legislative initiative, and the two houses of Parliament. Some important amendments were adopted by the houses upon royal proposal in the form of ordinary legislation. ${ }^{78}$ The Italian Statuto albertino, as well, did not provide for an amendment procedure. However, in practice, it was later amended by ordinary laws and consequently qualified as flexible constitution.

Within the member states of the German Confederation the situation was different. Most of their constitutions contained precise rules on amendment. In Luxembourg article 52 of the 1841 constitution of estates, required, for instance, the election of a Chamber with twice the number of members, a procedure respected in 1848 but violated by the coup d'état of 1856 . The German constitutions, established by octroi

\footnotetext{
${ }^{75}$ Published in the imperial official journal, RGBI. no 3, 185227.

${ }^{76}$ cf Lauvaux (n 6) 5 who quotes two ordinances of July 13, 1815 and August 19, 1815.

${ }^{77}$ Orig: 'tant pour lui que pour ses successeurs et à toujours'.

${ }^{78} \mathrm{cf}$ Georg Jellinek, Allgemeine Staatslehre ( $3^{\text {rd }}$ edn, Häring 1914), 527, mentioning the legislative act of June 9,1824 , modifying the rules on the renewal of the house of deputies from partial to integral renewal; Adhémar Esmein, Eléments de droit constitutionnel français et compare $\left(6^{\text {th }} \mathrm{edn}\right.$, repr. Editions Panthéon-Assas 2008) 575.
} 
in the period of the early constitutionalism, also recognized the necessity of special rules for amendment. A two thirds majority in both chambers was commonly required to revise the constitutional act. Yet, in spite of the shared exercise of the amendment power, the monarch retained the right to sanction all legislative acts and held a veto right. $^{79}$ The constitution of Prussia of $1848 / 1850$ established a flexible procedure. Amendments were to be adopted by the king and both chambers through the procedure applicable for ordinary legislation (art. 60 and 106).

Portugal's Carta of 1826 knew the most detailed procedure as described in its articles $140-143$. Any proposal of revision had to be supported by a third of the members of the chamber of deputies and the first amendment being allowed only after the end of an initial four-year period. A proposal had to go through three readings in the Chamber and to be submitted for final approval to the Chamber in the following legislature. This procedure was only required for 'constitutional provisions', defined by article 144 as 'those who concern the limits and respective powers of the Political Powers, and the individual and political rights of the Citizens'. Everything 'not constitutional' in this sense could be amended according to the formalities applying for ordinary legislation. Four additional acts were published in 1852, 1885, 1895-1896 and 1907 but only the second one strictly observed the detailed rules on amendment. $^{80}$

In absence of specific rules on amendment the development of some octroyed constitutions materialized naturally through informal constitutional change. This was, for instance, the case of the Statuto albertino that remained in force for almost a century. According to its wording, the government was responsible to the king only. Originally, it was understood as a rather conservative document that set up a strong constitutional monarchy. But its spirit was subsequently altered, at first in a liberal way, to adapt it to the parliamentary government of the late 19th and early 20th centuries, and then in an authoritarian direction under Benito Mussolini's Fascist regime (1922-1943).

\footnotetext{
${ }^{79} \mathrm{cf} \mathrm{Hummel}$ (n 23) 7 quoting the amendment procedures in Bavaria and Baden.

${ }^{80}$ cf Miranda (n 10) 50; Paulo Jorge Fernandes, 'Os Actos Adicionais à Carta Constitucional de 1826' (2012) 13 Historia Constitucional 563.
} 
Having examined process, form, legitimacy, substance and amendment of octroyed constitutions in $19^{\text {th }}$ century Europe, a clearer picture emerges as to what they really were. To answer the question raised in the title of this contribution: No, octroyed constitutions should not be considered as imposed constitutions. They form a category of their own. Moreover, it should be avoided to equate imposed constitutions with octroyed constitutions or to use the term octroi in a general manner to describe imposed constitutions.

Our Japanese colleague, Yasuo Hasebe, said that 'whether a constitution is imposed is a question of degree, not a question of kind'. ${ }^{81}$ In my opinion, an octroyed constitution is a kind of its own. It is decreed by a monarch claiming to hold the 'pouvoir constituant' through divine providence. It is in most cases domestically enacted and it is also self-imposed by a, more or less, enlightened monarch who sacrifices, more or less, voluntarily parts of his absolute power to share their exercise with a parliamentary body. As these charters commonly confirmed some of the liberal achievements of post-revolutionary constitutionalism they encountered tacit approval or passive tolerance of the peoples considering the substantive achievements resulting from the monarch's 'gift'.

\section{Bibliography:}

Bastid Paul, 'La théorie juridique des Chartes' (1953) 11 Rev. int. d'histoire politique et constitutionnelle 163

Fernandes Paulo Jorge, 'Os Actos Adicionais à Carta Constitucional de 1826' (2012) 13 Historia Constitucional 563

Ferreira Oscar, 'Les équivoques du „constitutionnalisme octroyé': un débat transatlantique I' (2015) 16 Historia Constitucional 67

Hartwig Matthias, 'What legitimises a National Constitution. On the importance of International Embedding', in Armin von Bogdandy, Pal Sonnevend (eds)

Constitutional Crisis in the European Constitutional Area,: Theory, Law and Politics in Hungary and Romania (Bloomsbury Publishing 2015)

Hasebe Yasuo, 'Imposed Constitutions (constitutions octroyées)', Max Planck Encyclopedia of Comparative Constitutional Law, 2016

Hummel Jacky, 'La Charte française de 1814 et le deutscher Konstitutionalismus : les inflexions d'une réception durable' (2014) 13 Jus Politicum 1

\footnotetext{
${ }^{81}$ Hasebe (n 4) para 1.
} 
Kirsch Martin, Monarch und Parlament im 19. Jahrhundert. Der monarchische Konstitutionalismus als europäischer Verfassungstyp - Frankreich im Vergleich (Vandenhoeck \& Ruprecht 1999)

Kotulla Michael , Das konstitutionelle Verfassungswerk Preußens 1848-1918, (Springer 2012)

Lacchè Luigi, 'Granted constitutions: The theory of octroy and Constitutional Experiments in Europe in the aftermath of the French Revolution' (2013) 9 EuConst 285.

Lacchè Luigi, 'Las Cartas otorgadas. La teoría de l'octroi y las experiencias constitucionales en Europa post-revolucionaria' (2010) 6 Fundamentos 269.

Lacchè Luigi, 'Le carte ottriate, La teoria dell'octroi e le esperienze costituzionali nell'Europa post-rivoluzionaria' (2009) 18 Giornale di storia costituzionale 229

Lauvaux Philippe, 'La technique de l'octroi et la nature de la Charte' (2014) 13 Jus Politicum 1.

Müßig Ulrike, 'Juridification by Constitution. National Sovereignty in Eighteenth and Nineteenth Century Europe' in Ulrike Müßig (ed.), Reconsidering Constitutional Formation I National Sovereignty, A comparative Analysis of the Juridification by Constitution (Springer Open 2016)

Prutsch Markus J., Making Sense of Constitutional Monarchism in Post-Napoleonic France and Germany (Palgrave Macmillan 2013)

Sardica José Miguel, 'A Carta Constitucional portuguesa de 1826' (2012) 13 Historia Constitucional 530

Stolleis Michael, 'Oktroi, oktroyierte Verfassung', in Handwörterbuch zur deutschen Rechtsgeschichte, HRG III (Erich Schmidt 1984) 1230

Voegelin Eric, Ruth Hein (tr.) and Gilbert Weiss(ed.), The Authoritarian State: An Essay on the Problem of the Austrian State, Collected Works of Eric Voegelin vol 4 (University of Missouri Press 1999) 